\title{
The Cradle of the New
}

\section{Humanitarian System?}

\section{International Work and}

\section{European Volunteers at the}

\section{Cambodian Border Camps,}

\section{I979-I993}

\author{
B ERTRAND TA I THE
}

\begin{abstract}
This article investigates the development of communities of practice in Thai-border Cambodian refugee camps for those international humanitarian workers involved at the frontiers of the Cold War. Under the management of the United Nations Border Relief Operation (UNBRO) and United Nations High Commissioner for Refugees (UNHCR) these camps brought together various NGOs and volunteers. Their prolonged presence at the border of Thailand enabled an epistemic community to emerge which facilitated the production of knowledge on refugees. Using oral histories and the archives of NGOs, this article investigates the development of an international community of practice in which Europeans played a key role, one which centred on the medical and social needs of refugees at a time of acute political instrumental use of humanitarian aid. The focus of humanitarians' work on genocide and associated trauma,
\end{abstract}

Humanitarian and Conflict Response Institute and Department of History, School of Arts, Cultures and Languages, Faculty of Humanities, University of Manchester, MI3 9PL; Bertrand.taithe@manchester.ac.uk

This article builds on papers given at the Reluctant Internationalists workshop in London, at the WADEM international conference in Manchester in 20I4 and at the history of medicine seminar at the University of Warwick. I also benefited from the insights of my colleagues Peter Gatrell and Pierre Fuller when I presented some of this work in our MA history of humanitarian aid at the Humanitarian and Conflict Response Institute in Manchester. I am very graceful to MSF for the full and unconditional access to their archives in Paris, to Norah Niland, Cheryl Coonahan and Andy Pendleton, who have kindly invited me to their reunion in Aranyaprathet, as well as to the many people who have engaged with me before, during and after that event. In particular, I would like to acknowledge Rony Brauman, Michael Neuman and the late Jacques Pinel, to whom this paper is dedicated. This paper represents the beginning of a larger project and augurs, I hope, further exchanges with them around these themes. Unfortunately it is now too late for Jacques. 
resulted in a clear political awareness that humanitarian aid had been used to maintain Khmer Rouge presence at the borders and that, in the peace negotiations of the early 1990s, it might facilitate their territorial and political return to a position of power.

'You can stop filming now - you no longer work for the CIA' laughed one veteran humanitarian worker addressing another, of Cambodian origin. Everyone laughed at this cruel but 'in' joke - the Cold War was over and the joke revealed openly many of the hidden tensions that made humanitarian aid at the Thai border such a flawed, yet 'successful' humanitarian operation. There was much humour in the otherwise poignant journey from the site of one refugee camp to another on Io January 2015. Around I80 volunteers and activists from the I980s had gathered in Aranyaprathet for a reunion which promised to bring together UN 'Cowboys', Cambodians, Thais and Voluntary organisations (Volags) ${ }^{1}$ workers back to the now eerily vacant sites of some of the largest refugee camps of the twentieth century.

This large gathering, the third in fifteen years, brought together all manner of workers from Asia, America and Europe. Some were local humanitarian workers who had found employment within the camps. Others had defined a career path for themselves and set up new non-governmental organisations (NGOs), such as Handicap International. Others had participated in the sudden growth of 'new' NGOs, such as the doctors from Doctors without Borders (Médecins sans Frontières; MSF). Finally, many had worked within the United Nations international network either in the bespoke United Nations Border Relief Organisation (UNBRO) or the United Nations High Commissioner for Refugees (UNHCR). The Thai border camps had been a focal point for coordinated humanitarian work in the I980s and had enabled global humanitarian exchanges in which Western NGOs and their workers played a crucial role.

This diversity was palpable in the meeting but, much like the relief work of the I980s, it focused on a strong sense of community, shared values and good work against terrible odds. Much like the camps themselves, the reunion was hosted by the Thai military. ${ }^{2}$ Yet the politics of the era now seemed distant. The retired Thai military authorities could now afford to reflect openly on their alignment with Chinese priorities and American anti-Vietnamese policies. Some of the structural violence imposed on refugees by this Cold War alignment remained unspoken in polite company. Yet a large number of Cambodians, perhaps 40 per cent of the gathering, had made the journey from either nearby Cambodia or from their diasporic resettlement further afield, mostly from the United States. For many this pilgrimage

1 The non-governmental organisation (NGO) and faith based organisation (FBO) terminology was not yet dominant at the border before I993. For the sake of making the difference between openly religious and secular organisations more explicit this article will nevertheless use this terminology.

2 This included the General Kitti who had led Task Force 80 in the I980s who 'revealed' his role in Cold War espionage. An open secret to all who had lived on the border. Frontière Khméro-Thailande, rapport d'activité, Nov. I983, Archives MSF (Paris), Thailande, I979-1983, I8. 
highlighted how these camps had also served as a painful gateway between East and West. These refugees had another agenda than just meeting with veteran Thai camp guards or UN administrators. They conducted memorial rites of their own; they gathered a little sacred dust from Site 2 or Khao I Dang, the largest and second largest of the Cambodian camps to bring back to the diaspora. The sites themselves now look like barely delineated expanses of scrubland or, in Khao I Dang's case, have been recently converted into an arboretum under royal patronage. Apart from very small signs nailed to posts or trees, there are hardly any other commemorative indicators or signifiers of the importance of these spaces. In fact there are many more references to the demining efforts than to the plight of refugees and displaced Cambodians in this still militarised border zone. ${ }^{3}$

Along a convoluted journey through check points the convoy of buses and army vehicles reached one site after the other. At every stop, all passengers gathered around a handheld megaphone which was passed from one speaker to another - whoever wished could then recollect - in English - their time in the camps - either as internees or international workers. A few anecdotes enlivened restrained but tragic accounts which brought many close to tears.

I was invited to be a historian in a memorial celebration ${ }^{4}$ because I had mentioned to one of the participants, the UN veteran Norah Niland, my interest in the significance of Cambodian camps for the history of modern humanitarian aid. ${ }^{5}$ This article relies largely on the interviews I conducted at this event and on work in Médecins sans Frontières's archives in Paris, which document the presence of this medical NGO in Thailand over twenty-eight years. It analyses the role of these camps in shaping how international workers and refugees engaged with trauma and the memory of genocide as a way to understand each other. It shows how this complex interaction shaped the humanitarian response and its approach to subjects, many of whom were destined for resettlement either in the West or in a country devastated by war and genocide. ${ }^{6}$ By looking in turn at the camps, the international volunteers and how they engaged with the traumatic experience of genocide victims, this article shows how humanitarian internationalists 'invented' modern humanitarianism through their practices and through the facilitation of knowledge production. This humanitarianism in turn evolved into a global political 'lobby' against the Khmer Rouge's presence at the United Nations and at the peace negotiation table in the

3 Although at peace, Thailand and Cambodia regularly contest their exact frontiers.

${ }^{4}$ David Mosse, 'Anti-Social Anthropology? Objectivity, Objection and the Ethnography of Public Policy and Professional Communities', Journal of the Royal Anthropological Institute, (N.S.) I2 (2006), $935-56$.

5 Emmanuel Adler and Peter m. Haas, 'Epistemic Communities, World Order and the Creation of a Reflective Research Program', International Organization, 46, I (I992) 367-90; James K. Sebenius, 'Challenging Conventional Explanations of International Cooperation: Negotiation Analysis and the Case of Epistemic Communities', International Organization, 46, I (I992) 323-65; Bruno Cabanes, The Great War and the Origins of Humanitarianism 1918-1924, (Cambridge: Cambridge University Press, 20I4).

6 Bertrand Taithe and John Borton, 'History, Memory and "Lessons Learned" for Humanitarians', European Review of History, forthcoming, 2016. 
new Cambodia. This shift, late in the day, also revealed pent up anger against the manner in which humanitarians had, almost unwittingly, maintained the political and military system which had enabled Khmer Rouge survival throughout the I980s. The campaigns of the late I980s revealed how profound the experience of looking after Cambodian refugees primarily as victims of the trauma of the Khmer Rouge genocide had been.

\section{Imagined Humanitarian Communities}

In the humanitarian narrative of the twentieth century the Cambodian camps became a focal point of sustained engagement and collaboration between the UN and nongovernmental organisations, particularly from around I979 until I993. While the contemporary camps at the border of Afghanistan Nicaragua, in the horn of Africa and in Sudan have also played significant roles in the actual shaping of humanitarian practices - as Fiona Terry argues - they are not the object of similar commemorative practices and reunions. ${ }^{7}$ Among the scores of victims at the end of the Cold War, displaced Cambodians had a particular aura which referred to the extraordinary brutality of the Vietnam Wars and the Cambodian 'self-genocide'. These events echoed powerfully across Europe and played a crucial part in the shaping and reshaping of European left wing politics from the I960s until I989. Unlike other contemporary crises, the Indochinese refugee crisis of the I980s opened the gates to the largest resettlement programme in Europe since the end of the Second World War. But in the camps, as well as on arrival in Europe, the encounter with the Cambodians was made more complex by the growing conviction that their story was uniquely 'traumatised' - which in turn gave rise to the idea of secondary trauma for those who have worked with them. Over a period of thirteen to fifteen years, these closed camps were sites of international work which combined very diverse relief activities (from food relief to healthcare, policing, education and religious succour) with a relatively stable environment where knowledge was co-produced by European and American academics and humanitarians. Many of these academics and humanitarians encountered genocide victims afresh with the intellectual tools and historical baggage arising from the European experience of the Holocaust. Though much research was defined by the camps, it found its uses in Europe and North America, where many refugees were resettled. This considerable resettlement effort contributed to a more dislocated experience of what was in 'the field' and what was a concern for the 'West'. Cambodian people became refugees in, and later citizens of, the countries of origin of the humanitarian workers, such as France and Germany. They are now therefore Europeans in their own right, but their story of genocide talked to older European experiences of genocide through the interpretative framework devised in the camps.

7 Fiona Terry, Condemned to Repeat? The Paradox of Humanitarian Action (Ithaca: Cornell University Press, 2002). 
For the humanitarian workers, a common way of working and responding to this encounter shaped what we might call an epistemic community. The concept itself, borrowed from Haas, describes how groups, through work socialisation, come to share professional identities, understandings of situations, norms, policy practices and the discursive foundations of their worldviews. This article argues that beyond well-studied government agencies or international bureaucracies, voluntary groups and NGOs coalesced, as they grew rapidly, in a handful of significant sites on at the margins of Cold War conflicts. Among these sites the Thai border camps are a prime example of converging practices and consensual analyses within a 'human rights framework'. ${ }^{8}$ This very particular expatriate setting mixed nationalities within the spaces of sociability and work at the borders of the two countries and became perceived as a 'community', a group endowed with a range of imagined virtues as explored by Daniel Immerwahr.' 'The border' became a liminal spatial entity in its own right. A 'frontier spirit' defined its makeshift appearance and transience and it echoed strongly culturally for European, American and Australian volunteers. In turn this spirit defined their sense of community. ${ }^{10}$ The references made at the reunion at the border, some thirty years later, to 'cow boys and girls' would, in another setting, be entirely negative. In a border setting, as imagined then and as it is remembered now, they anchor the humanitarian experience of the I980s in older myths of path-breaking initiative and self-reliance.

This imagined sense of community was grounded in a range of practices which have had long-term influence. Some of the 'spaces of aid' identified by Lisa Smirl including this particular distance between the 'field' as lived by humanitarians and places in need of aid - took form in the very constrained political setting of this of this late Cold War frontier. ${ }^{11}$ Despite the many ambiguities of relief work 'at the border', ${ }^{12}$ a success narrative was constructed and established by the time the camps were evacuated, dismantled and burned. For a significant generation of humanitarians, the space at the edge of Cambodia became the cradle of their career, while for many NGOs it became a site of continuous and systemic institutional growth. Reflecting on these camps as the spatial configuration of 'epistemic' exchange and the consolidation of an international professional world, one can reflect on what internationalists learned when they gathered and collaborated in the final decade of the Cold War.

8 Dennis Gallagher, 'The Second International Conference on Indochinese Refugees: A New Humanitarian Consensus?', Centre for Policy Analysis and Research on Refugee Issues (May, I989), Archives MSF, Papiers François Jean, Boite ABILE réfugiés MSF Cambodge 93, UNDHA \& Co., I3.

9 Daniel Immerwahr, Thinking Small: The United States and the Lure of Community Development, (Cambridge, MA: Harvard University Press, 20I5).

10 There were of course volunteers from the Indian subcontinent and other parts of Asia. The funding of the 'border' work was primarily Japanese (46.5 per cent) rather than American or European, but the experience of their work in this operation falls beyond the remit of this article.

${ }^{11}$ Lisa Smirl, Spaces of Aid: How Cars, Compounds and Hotels Shape Humanitarianism (London: Zed Books, 2OI5), 4-II.

12 These were openly denounced at the time. See Jean-Christophe Rufin, Le Piège Humanitaire (Paris: Lattès, I986). 


\section{The Cambodian Camps}

Reflecting on the state of the humanitarian aid in the early I990s, Charlotte Benson produced a synthesis of the coordinated Cambodian relief work for the British think tank the Overseas Development Institute of London. Her short text reflected on a mission now complete and on what lessons might be learned from this experience. ${ }^{13}$ By 1993 most of the camps had, with the exception of a few Khmer rouge hideouts, been closed and dismantled. 'Mission accomplished!?' asked with some scepticism the MSF representative in Bangkok in his report to the president of the French NGO. ${ }^{14}$ The international political process ending war in Cambodia was formally agreed in Paris on 23 October I99I. It ended both a civil war of twenty years and fifteen years long war with Vietnam. Bringing together all the rival factions, including the Khmer Rouge supported by China and Thailand, and the nationalists and royalists supported by the United States and France, the process gave precedence to national reconstruction over the resolution of all conflicts or retribution for the unspeakable crimes of the I970s. In practice, this 'peace' remained fragile until the Khmer Rouge weakened in the I990s when they lost their powerful allies. This ambiguous peace accord concluded the Indochinese wars of decolonisation which had so long been the most violent conflict zone of the Cold War.

It also ended the international humanitarian effort at the border of Cambodia, relocating it instead inside the country, with many NGOs focusing much more on development issues than emergency relief work. A uniquely centralised UN cooperation led by UNBRO ceased to exist when UNHCR was tasked with the repatriation of its wards. The final mission was masterminded by Sergio Vieira de Mello, who transformed its mandate in March 1992 and conducted a successful operation despite many initial concerns. ${ }^{15}$ As Benson noted, 'UNBRO was unique and according to most observers a highly successful venture'. ${ }^{16}$ As the outcome of a successful peace process, the end of humanitarian relief on the border seemed a victory against all odds.

From the Vietnamese invasion of Pol Pot's Khmer Rouge Kampuchea in December 1978 onward, Thailand had become the reluctant host to a vast number of Cambodian displaced people whose status remained contested until the end of the camps. ${ }^{17}$ While UNHCR managed to set up one very large camp inside

13 Charlotte Benson, The Changing Role of NGOs in the Provision of Relief and Rehabilitation Assistance: Case Study 2 - Cambodia Thailand, ODI, Working Paper 75, I993.

14 Telegram from Gilles Delmas to Rony Brauman, 3 Mar. I993, Archives MSF (Paris), Thailande, Khao I Dang I990-I992 rapports Kit Medi RPI.

15 Gilles Germain, 'Note de synthèse à François Jean', 3 Feb. I993, Archives MSF, Papiers François Jean, Boite ABILE.

16 Benson, Changing Role, 30.

17 Thailand was not a signatory to the I95I convention. Its policy alternated between a brief open door policy to a 'deterrent one'. Christel Thibault, L'Archipel des Camps: L'Exemple Cambodgien (Paris: Presses Universitaires de France, 2008) I8-9; ibid. 'Terres Spoliées, Terres Minées: Les Obstacles au Retour des Réfugiés Cambodgiens et les Contraintes de la Reconstruction Nationale', in Luc Cambrézy and V. Lassailly-Jacob, eds., Populations Réfugiées: de l'Exil au Retour (Paris: IRD, 200I), $353-76,359$. 
Thailand $^{18}$ (though located some twenty miles in front of the first line of genuine planned military resistance), most camps were set up as a buffer state on the edge of the Vietnamese advance. Most were built on the contested border zone between Cambodia and Thailand. The camps contained a vast, captive population from which the Cambodian parties recruited troops fed by humanitarian food relief. From I975 until the forced repatriation of most Cambodians in $1992-3,{ }^{19}$ seventy-two camps of varying size and permanence have existed. ${ }^{20}$ Most border camps were managed by a joint mission by UNICEF-ICRC until the creation of a specific organisation, UNBRO, enabled it to take over in $1982 .{ }^{21}$ The UNHCR only managed one of the largest camps from I983 onwards, Khao I Dang. This camp was the only official gateway for overseas resettlement until $1989 .{ }^{22}$ Because it was the camp most open to foreign visitors it soon became emblematic of all refugee camps despite its singularity. The Thai military had oversight of all refugee camps, but they surrendered their political management to the different Cambodian factions opposed to the Vietnamese. As a result, the royalist FUNCINPEC party, the Khmer People's National Liberation Front and the Khmer Rouge ruled the various camps. ${ }^{23}$ These factions and their militias were supported by the French, Americans and Chinese respectively, even as they formed the uneasy Coalition Government of Democratic Kampuchea in 1982 under the leadership of Prince Norodom Sihanouk. In effect, the genocidal Khmer Rouges under Khieu Samphan, the foreign secretary of the coalition, remained in control of the UN representation for Cambodia throughout the period, while their troops received the bulk of military assistance. Their guerrilla outnumbered that of their competitors by a factor of three to one and was widely regarded as the most effective combatant force. ${ }^{24}$ This humanitarian arrangement associated the open needs of a vast displaced population with the unspoken needs of Cold War strategists - Thai, Chinese as well as American - seeking to contain Vietnamese hegemony over Indochina. A covert guerrilla war ensued throughout the I980s during which the Vietnamese dominated during the dry season while their foes were most active in the rainy season. The camps' military importance declined after the successful Vietnamese offensive of 1984 , when the camps were regrouped within the border zone of Thailand.

18 Véronique van Gool, Les Camps de Réfugiés Cambodgiens en Thaïlande: Rôle du Haut Commissariat des Nations Unies pour les Réfugiés dans la Mise sur Pied et la Gestion de ces Camps (Paris: Institut Universitaire de Hautes Études Internationales, 2000).

19 'Operation Plan, Repatriation of Cambodian Refugees and Displaced Persons' Jan. I992, Archives MSF, Paris, Thailande, Khao I Dang I990-I992 rapports Kit Medi RPI.

${ }^{20}$ http://www.websitesrcg.com/border/border-camps.html (last visited Apr. 20I4), a website by Richard Rowat.

21 Terry, Condemned to Repeat, I3I; Linda Mason and Roger Brown, Rice, Rivalry and Politics: Managing Cambodian Relief (South Bend: University of Notre Dame Press, 1983).

22 Thibault, L'Archipel des Camps, 67.

23 Ben Barber, 'Feeding Refugees, or War? The Dilemma of Humanitarian Aid', Foreign Affairs, 76, 4 (I997) 8-I4; Lindsay French, 'From Politics to Economics at the Thai-Cambodian Border: Plus Ça Change...' International Journal of Politics, Culture, and Society, I5, 3 (2002) 427-70.

24 Terry, Condemned to Repeat, I24-5. 
Unlike the smaller Karen camps, which still exist today at the border of Myanmar, and which tend to look far more like hillside villages, Cambodian camps such as Khao I Dang and Site 2 grew into veritable cities. Khao I Dang lasted longest (from I979-I992), with a population of 40 to 57,000 in the I980s; Site 2 hosted about I40,000 people in I989 when the Ford foundation survey attempted a demographic study, increasing to I98,582 in I99I. The figures remained a moot point throughout the period since the overestimation of refugee numbers by camp management - with some considerable complicity from some humanitarians - enabled the food rations to feed both soldiers and the black market sustaining the war economy. ${ }^{25}$ Site 2 had sub-camps which formed a conurbation rather than a unique space. Like Khao I Dang it was open to NGOs and urban. By the late I980s it had restaurants, a Buddhist monastery, many workshops and even 'universities'. Like all the other camps under UNBRO management, however, it was also a closed environment at night, with a curfew of 4 p.m. for foreigners. Thai authorities demanded that these camps retained an artificial appearance of transience and permanent structures were banned the exception of very few administrative barracks. Apart from a few rare concrete floors, all structures remained wood, straw and bamboo built - giving them a rural feel which their continued presence over many years might have made redundant.

Khao I Dang and Site 2 grew to become focal points for NGO work; American, Australian, Japanese and European funding and international academic research. ${ }^{26}$ Unlike the Khmer Rouge controlled camps, they welcomed Voluntary Organisation (Volag) initiatives, offering fertile ground for the deployment of new resources such as European Community funding. They brought together new European NGOs such as MSF and Handicap as well as older, often religious, European and American organisations, some of which had long experience in the region dating back to the Korean war or earlier. ${ }^{27}$ The humanitarian apparatus of Cambodia was relatively stable over time and one of the most holistic in the late twentieth century. Humanitarians provided a range of services and projects which included education, health and mental health, policing and peace programmes. While its explicit remit was relief there is no doubt that the genocide gave a particularly militant significance to this relief work even if it was mired in the contradictions of hosting Khmer rouge armies as refugees in order to enable them to fight the Vietnamese invader.

In this troubled context, the camps favoured research and reflexion, making a long-lasting contribution to the shaping of humanitarian relief work and knowledge specific to refugee work. On one level these communities of practice can be described as epistemic communities. Using Ludwik Fleck's cultural notions of 'thought

${ }^{25}$ Norah Niland, 'The Politics of Suffering: A Case study on the Use and Abuse of Humanitarian Assistance', MPhil Thesis, Trinity College Dublin, I99I, 35-8.

26 B. Feldstein and R. Weiss. 'Refugee Camp Medical Care During the Cambodian Disaster Relief at Khao I Dang', in Proceedings of the Second World Congress on Emergency and Disaster Medicine, (I98I), $372-83$.

27 Correspondence Francis Charon to Mr Molinier, EEC, Nov. I986, Archives MSF (Paris), Courier Francis Charon, 1986. 
collective ${ }^{28}$ in science, rather than Kuhnian concepts of paradigm shift, one can reflect on the localisation and diffusion models of epistemic shifts throughout these specific spaces. Knowledge produced and diffused locally in these camps has since reached deep and far in the nascent international humanitarian networks. The empirical knowledge embodied in practices, manuals and guidelines was transmitted from one organisation to the next, with field workers translating from and into English the modus operandi of partner organisations and reporting back to headquarters. Within voluntary organisations, international volunteers often served at least a year at the Thai border. This experience then shaped much of their perspective on humanitarian aid for their subsequent career. These careers in turn took many of these workers around the emergencies of the world during the subsequent thirty years. Frontier veterans are to be found in almost every leading NGO and foundation at decision making levels. The experience of working in the Thai border camps is thus not only a personal matter but also one that impacted the shaping of what was later called 'the humanitarian system' as a whole. Because individual experience was so grounded in a community of practice, it helped to produce many of the assumptions and certainties which have enabled humanitarian work to emerge as a field ripe for 'professionalisation'. This process was rooted spatially in a profound manner. These sites enabled the making of authority, integrity and trust, as professional communities of humanitarian emergency relief workers were constituted and operated over time. While dysfunctional in many ways, these camps were also formative for the humanitarian sector and provided a field of practice at a moment when the sector expanded most.

\section{The Internationalists and Culture Shock}

The range of volunteers who made the journey to Cambodia was varied and diverse. It reflected a range of historical trends, including the French continued cultural and social bonds with Indochina and the United States's reinvention of its role in the region after the fall of Saigon. ${ }^{29}$ The camps were not the only focal point of humanitarian work in the Indochinese region. Much European media attention was directed at Vietnamese boat people. ${ }^{30}$ Television teams boarded humanitarian rescue

28 R.S. Cohen and T. Schnelle, eds., Cognition and Fact - Materials on Ludwik Fleck (London: Springer, I986).

${ }^{29}$ Heather Marie Stur, "Hiding Behind the Humanitarian Label”: Refugees, Repatriates, and the Rebuilding of America's Benevolent Image after the Vietnam War', Diplomatic History, 39, 2 (20I5) 223-44.

${ }^{30}$ Ben Kiernan, How Pol Pot Came to Power: A History of Communism in Cambodia, 1930-1975, 2nd edn (New Haven: Yale University Press, 2004); Ben Kiernan, 'The American Bombardment of Kampuchea, I969-I973', Vietnam Generation, I, I (I989) 4-4I; Ben Kiernan, ed., Genocide and Democracy in Cambodia: The Khmer Rouge, the United Nations, and the International Community (New Haven: Yale University Press, I993); David Chandler, The Tragedy of Cambodian History: Politics, War, and Revolution since 1945 (New Haven: Yale University Press, I99I). 
ships such as the German Cap Anamur ${ }^{31}$ and the French Île de Lumière to produce some of the most spectacular representations of humanitarian work to date. ${ }^{32}$ The French Ille de Lumière provided French intellectuals opportunities for public reconciliation and Raymond Aron and Jean-Paul Sartre, long divided by the politics of the Cold War, thus reconciled at the very end of their lives. These television experiments in humanitarian rescue work enabled even very conservative media like French state television the opportunity to cross a number of visual and representational thresholds. ${ }^{33}$ Within the French humanitarian sector it also led directly to the split of a then rather modest Médecins sans Frontières into two organisations, with Doctors of the World (Médecins du Monde) led by Bernard Kouchner emerging as a rival organisation in I980. MSF opponents to the ship pointed out that the real work was in the refugee camps and not in the TV studios, but the schism went beyond these tactical concerns to encompass a more profound conflict on the aims of humanitarian aid and on its politics. ${ }^{34}$

Yet within the camps themselves politics was often an after-thought, and the volunteers came with a focus on relief work rather than a clear understanding of the complex local situation. Some like 'Marianne' ${ }^{35}$ moved from San Francisco where she worked with refugees to Aranyaprathet to provide much needed medical care to the impoverished Thai villages surrounding the refugee camps. Though not populated by refugees, the so-called 'affected Thai Villages' were identified for matching relief work by the international relief organisations. ${ }^{36}$ She remained near the camps for three formative years of her life before returning to a career in community nursing. ${ }^{37}$ Others came because they spoke Thai, like Susan Walker from Minnesota, whose father had served for Air America in the covert war in Laos, and who had grown up in the region. ${ }^{38}$ Susan, who had arrived to work with the American Refugee Committee (ARC) to follow her medically trained sister Pat, became ARC's regional director at the age of twenty-six and stayed for the entire period. With the growth of humanitarian response corresponding to the vastly increased size of the settlements, the number and range of volunteers grew in proportion. MSF, which had sent its first

31 Patrick Merziger, "The "Radical Humanism" of "Cap Anamur" / "German Emergency Doctors" in the I980s. A Turning Point for the Idea, Practice and Policy of Humanitarian Aid', European Review of History, forthcoming, 2016.

32 Xavier Emmanuelli entitled it 'Un Bateau pour Saint Germain des Pré', Xavier Emmanuelli, Les Prédateurs de l'Action Humanitaire (Paris: Albin Michel, I99I) 207-I4. Bertrand Taithe, 'Reinventing (French) Universalism: Religion, Humanitarianism and the French Doctors', Modern and Contemporary France, I2, 2 (2004), I47-58; Bernard Kouchner, Île-de-Lumière (Paris: Ramsay, I98I).

33 http://www.ina.fr/video/CAB790078080I (last visited 26 Apr. 2015).

34 Eleanor Davey, Idealism Beyond Borders: The French Revolutionary Left and the Intellectual Origins of Humanitarianism, 1954-1988 (Cambridge: Cambridge, 2015).

35 Marianne is a pseudonym. Interview took place, Io Jan. 20I5.

36 Thibault, L'Archipel des Camps, 30; Health Conditions in the Kampuchea-Thailand Border Encampments, Report of the WHO/UN Health mission to the Kampuchea-Tailand Border, Feb. I983, Archives MSF (Paris), Thailande I979-I983.

37 Interview with 'Marianne', Io Jan. 2015.

${ }^{38}$ Biloine Young, 'My Heart It Is Delicious': Setting the Course for Cross Cultural Health Care, the Story of the Centre for International Health (Minneapolis: Afton Press, 2008), 38-4I. 
'mission' in 1976 to work under the banner of other NGOs, grew to become one of the major medical providers in the NGO world, running the referring hospital in Khao I Dang. European MSF volunteers were originally sent to Bangkok where they were welcomed in a house run by a coordinator and then dispatched to the relevant camps on the borders, a few hours' drive from the capital city. ${ }^{39}$ While originally a purely medical volunteer association, MSF had to develop a range of other humanitarian professions in order to support prolonged medical work. In particular, the need for 'logisticians', handymen and planners led the pharmacist Jacques Pinel to recruit a range of French travellers, 'routards' - or long-term resourceful backpackers who, in the spirit of the post-' 68 world, travelled the world to experience it. ${ }^{40}$ These were deemed to have the required qualities to support international relief work: resourcefulness (débrouillardise) and autonomy. Their survival skills matched the need for resourcefulness the new environment presented. With supply lines stretched to extreme - the flights were subsidised by Air France but the provisions of goods had to rely on local markets and supply chains - logistics became central to the humanitarian escalation. The history of humanitarian logistics, for instance in the case of MSF, whose logistics' section celebrates its thirtieth anniversary in 20I6, is closely linked to the large and sustained efforts required to meet the sanitary and medical needs of these city camps. The information exchange between a range of practitioners and volunteers cross fertilised the humanitarian sector. ${ }^{41}$

The largest border camps of Site 2 and Khao I Dang were both close to the border town of Aranyaprathet in Sae Kaeo Province, on the other side of the Cambodian town Poipet, with which it had been hitherto linked by a train line. The small town became host to all the major actors in the humanitarian field present in the camps from MSF to the ICRC, ${ }^{42}$ American Relief Committee, the UNHCR and UNBRO. A community of practice could grow effectively because these groups of different nationalities mixed socially within the confines of Aranyaprathet after the camp curfew of 4 p.m. Much of the literature on Cambodia devotes significant space to the culture shock of humanitarians encountering for the first time profound rurality in extremes of heat and humidity. Children riding buffaloes and the painstaking rice cultivation of the surroundings contrasted with the high density and boredom of the camps. For the international workers, most of them young, the town of Aranyaprathet became a second home - with its very limited entertainment possibilities, its ritual, and from all accounts quite wild, Red Cross parties on Friday night or the MSF 'soirées' on Saturday night - a place where partners were found and lost. The social life in 'Aran' was matched by that found in the Bangkok headquarters.

\footnotetext{
39 Missions Médecins sans frontières Thailande Bangkok, Cahier de Transmission, Archives MSF (Paris), Thailande, divers.

${ }^{40}$ Interview with Jacques Pinel, 7 Mar., 20I3.

${ }^{41}$ P. Baudesson-Deneu, 'Amputés Traumatiques Insérés dans un Atelier d'Appareillage en Thailande: Étude des Positions de Travail.' Journal d'Ergothérapie, 9, I (I987), 7-I2.

42 Jean-Philippe Lavoyer, 'Réfugiés et Personnes Déplacées - Droit International Humanitaire et Rôle du CICR', Revue Internationale de la Croix-Rouge, 77, 8I2 (I995)I83-202.
} 
On arrival in our mission we had considered that we could do without parties and limit them to the arrival and departures of the new staff in Bangkok, in order to organise 'parties' with a view to entertain. The MSF protested so much that we have 'institutionalised' festive events. Every time it is an opportunity for all the MSF [staff] to really get to know one another and to meet at the same opportunity our colleagues and travelling companions from other organisations (ESF, ICRC, UNBRO, OHI, UNHCR, EEC, SIPAR ... $)^{43}$

The town also became a place in which the experience of culture shock became mediated by preceding generations of workers and their 'sharing' of experience. Though their perspective remained to a very considerable sense ethnocentric, in particular in relation to professional practice or, for instance, the understanding of what was dirty or clean, ${ }^{44}$ this did not undermine the profound impact of this cultural encounter. Humanitarian workers were in effect cut off from the people they had come to help most of the time. Though this might be called an early instance of 'bunkerisation', it was less a reflection of a security anxiety, although the camps and the roads did remain unsafe, than the geopolitical priorities of the Thai and Cambodian military.

Camp politics were extremely confusing for people used to binaries. While European media and support groups eagerly embraced Afghan freedom fighters, including the iconic Islamist warlord Ahmed Shah Massoud, the portrait of the Cambodian resistance to the Vietnamese remained more confused and subject to contestation. The Khmer Rouge regime remained the legitimate UN seat holder, and the highly ambiguous figure of Prince Sihanouk wove a web of intrigues between Europe, North Korea and China. ${ }^{45}$ The complexities of a three way Cold War front eluded the wider public. If humanitarians were naive at the moment of their first encounter with Cambodia, they soon found themselves at the forefront of intelligence gathering. One American nurse, who arrived in 1985 and who has since remained in Cambodia, admitted that she had arrived in Cambodia without any knowledge of the Vietnamese wars or of the geopolitics of the region. ${ }^{46}$

However, intelligence gathering became a common activity for all middle ranking expatriates at the border. Humanitarian workers sent monthly summaries of the complex intrigues and fast changing security situations from the Thai border back to headquarters. The MSF briefing, for instance, echoed the hearsays and rumours exchanged between humanitarian workers and the security apparatus. ${ }^{47}$ NGOs

43 Missions Médecins sans Frontières Thailande Bangkok, Cahier de Transmission, Archives MSF (Paris), Thailande, divers, unpaginated. The cost was distributed among staff and seems to have been heavily reliant on the provision of alcohol (including local Mehkong whisky 'for the drunkards').

${ }^{44}$ Soizick Crochet, 'Le Péril Fécal', in Rony Brauman, ed., Utopies Sanitaires (Paris: Le Pommier, 200o) $2 \mathrm{I}-45$.

45 Jean-Marie Cambacérès, Sihanouk: Le Roi Insubmersible (Paris: Le Cherche Midi, 20I3); Bernard Hamel, Sihanouk et le Drame Cambodgien (Paris: L'Harmattan, I992); Charles Meyer, Derrière le Sourire Khmer (Paris: Plon, I97I); Milton E. Osborne, Sihanouk: Prince of Light, Prince of Darkness (Honolulu: University of Hawaii Press, I994).

46 Interview with Arlys Herem, present on the camps from I985 until I990 with ARC, IO Jan. 20I5.

47 'Synthèse de l'activité régionale du trimestre', Jun. I989; 'La Diplomatie de Bangkok et le Conflit Cambodgien', Jan. 89, Archives MSF (Paris), Thailande, Rapports Visites Infos Générales I99i, I992, I993, OPE 4. 
exchanged information and intelligence pertaining to their own security or to the more arcane negotiations taking place around Cambodian elites.

Constituted socially as a community, the international workers also benefited from flexible funding with recurrent funding originating from states such as Japan, the United States and the European Community, as well as national sources and wider public fundraising. The range of projects in the camps reflected their semipermanence and combined emergency relief work, primarily on health matters, with developmental agenda and concerns over the consequences of enforced idleness and dependency for displaced people. ${ }^{48}$ Furthermore, the vast resettlement programme which had transformed Khao I Dang into a transit camp for the West (primarily the United States, France, Canada and Australia in order of importance) also literally brought home issues arising from work in the camps. The unfairness of resettlement policies, uniquely focused on one camp at the expense of the others, generated the so-called 'Khao I Dang fever', in which Cambodians, on hearing a rumour of new resettlements or the regularisation of the 'illegal' residents of the camp (literally refugees hiding in a refugee camps), risked their life to escape the UNBRO camps to enter the well-guarded UNHCR one. ${ }^{49}$ As the powerless witnesses of these sordid transactions, humanitarians could only relate their dismay at the inequality and unfairness of the international response. The experience was often lived as a traumatic one. Some, like 'Marianne', found it difficult to return from the camps and to 'readjust' to a normal life 'at home. The personal experience of dealing with 'traumatised' people proved hard to convey and profoundly impacted the camp workers.

Yet humanitarians could also rely on strong support networks for their own work which sustained resettlement, and there were possibilities of continuing this work in Europe, North America or Australia. Unlike with many other refugee situations, welcome committees transcending political boundaries had been set up in the expatriates' countries of origin. In France, for instance, the Indochinese refugees were given preferential treatment and relied on deeply anchored support networks which benefited from support from the Catholic Church, military veteran associations and solidarity networks dating from the French Indochinese War. ${ }^{50}$ These networks reached far across provincial France. For instance, the largest milk production cooperative in the west of France, in Ploudaniel, Brittany, supported humanitarian work in Cambodia as part of its 'Third World' solidarity agenda in

48 See, for instance, the 'Programme de Technologie Appropriée' pour Aider les Réfugiés Cambodgien et Autres, Promu et Financé par le Comité Européen d'Aide aux Réfugiés, I98I, Archives MSF (Paris), Thailande, divers.

49 The Thai forces, including Task Force 80, were organised as much to guard the camps as to protect the frontier. Niland, 'Politics of Suffering', 38.

${ }^{50}$ Claude Gilles, De l'Enfer à la Liberté: Cambodge, Laos, Vietnam: Accueil des Réfugiés en France: Documents et Témoignages (Paris: L'Harmattan, 200o); Karine Meslin, 'L'Accueil des Boat People: une Mobilisation Politique Atypique', Plein Droit, 70 (2006). http://www.gisti.org/spip.php?article2 I3 (last visited I4 Apr. 20I5). 
collaboration with Association Française de solidarité Cambodge, founded in 1980. ${ }^{51}$ Networks of solidarity blossomed in many odd areas of the French provinces. By I989 France Asia Press could bring a 'sample' of twenty-eight Franco-Cambodian associations located in the provinces for a debate with the two leading medical French NGOs in the camps. ${ }^{52}$ The camp field work made humanitarians legitimate voices and experts on Cambodia, but their presence in these camps relied increasingly on the quality of the work they could deliver. Over fifteen years of humanitarian work, one finds routine references to one's personal accomplishment in the face of insurmountable initial odds. 'At my arrival, everything needed to be done' ${ }^{53}$ This Sisyphean sense of eternally new toil is deeply impressed in the archives and contrasts with the humbler recollections of longer-term practitioners. ${ }^{54}$

\section{Understanding Traumatic Experiences}

If expertise served as a currency of status - establishing the cultural capital and legitimacy of humanitarian workers, and making them experts in the eyes of international funders and perhaps even some of their 'beneficiaries' - it was also a product of the camps. Much knowledge was produced on camp conditions, for obvious reasons, but the dominant science that emerged from the interaction of expatriates, visiting academics and refugees was primarily developed as a science of genocide survival. Most of the refugees had fled the Vietnamese invasion rather than the Khmer Rouge massacres of the I970s, but their plight became increasingly defined by the genocide experience of the Khmer Rouge era. Humanitarians were often unwilling or resistant to hosting academic visitors, ${ }^{55}$ yet research projects flocked to the camps of Khao I Dang and Site 2 in the hope of making sense of what they contained and represented in order to bring back knowledge about surviving genocide and, later, its impact on Cambodian migrants resettled in the West.

The very large camps on the Thai border created an urban setting which contrasted with much rural development work practiced in the I970s. ${ }^{56}$ Camps thus enabled the study of a range of new issues for humanitarian social investigation

51 Eugène Calvez, 'Coopération Agricole et Préoccupation Tiers-mondiste: un Exemple Significatif en Bretagne', La Gouvernance des Entreprises coopératives (2007), I45-55.

52 France Asia Press, Meng Heang Panh to President of MSF, I6 Dec. I989, Archives MSF (Paris), papiers François Jean, Abile.

53 Christine Ramard, 'Rapport de Fin de Mission à KID', Oct. I99I- Jul. I992, part I, Archives MSF (Paris), Thailande, Khao I Dang I990-I992, rapports Kit Medi RPI.

54 Interview with Arlys Herem, present in the camps from I985 until I990 with ARC. Interview Io Jan. 2015 .

55 The archives are replete with ill-tempered exchanges regarding the desirability or the risks of associating research with humanitarian activities. These disputes notwithstanding, research did take place and produced new knowledge. See, for instance, the letter of François Nosten (ccd Nick White of Mahidol University) to Philippe Biberson, coordinator MSF in Bangkok, 6 Nov. 1987, Archives MSF (Paris), Thailande, I979-I983 [sic].

56 Uma Kothari, ed., A Radical History of Development Studies: Individuals, Institutions and Ideologies (London: Zed Books, 2005). 
and experimentation. In particular, the genocide survivor status, which emerged from the fuller understanding of the atrocities committed under Pol Pot, ${ }^{57}$ led some humanitarian workers to concentrate on mental health issues and trauma. The scale of the so-called 'self-genocide' of Cambodia between I975 and I978 enabled new research to take place at the same time as European and American psychiatrists were increasingly concerned with the study of trauma in second generation survivors of the Holocaust, ${ }^{58}$ and, by the early I980s, as new categories of more diffuse traumatic experiences arising from the Vietnam war were labelled Post Traumatic Stress Disorder (PTSD). ${ }^{59}$ Their practice thus built on the most recent psychiatric Western perspectives of the I970s, which represented the survival of genocide as trauma. ${ }^{60}$ Cambodian sufferings were often referred to as those of victims of concentration camps. ${ }^{61}$ Ironically, the camps where victims lived were now humanitarian spaces, and it was the specific features of a closed environment which made Cambodia so attractive for academic researchers.

The systematic study of (Western) notions of trauma on child survivors was enriched by the possibility of follow up among a captive audience study group. ${ }^{62}$ Contemporary studies generated unique science from the prolonged studies of several generations of adolescents in a stressful and alienating environment. Within Site 2 or Khao I Dang, longitudinal studies of group psychology became possible. ${ }^{63}$ As

57 The blockbuster The Killing Fields, filmed at the border and in Thailand with Cambodian actors, made this awareness global, but it built on prior knowledge. David Chandler, "“The Killing Fields" and Perceptions of Cambodian History', Pacific Affairs, 59, I (I986), 92-7; Benoît Fidelin, Prêtre au Cambodge: François Ponchaud, l’Homme qui Révéla au Monde le Génocide (Paris: Albin Michel, I999).

58 Harvey A Barocas and Carol B. Barocas, 'Manifestations of Concentration Camp Effects on the Second Generation', American Journal of Psychiatry, I30, 7 (I973), 820-I; Didier Bertrand and Odette Lescarret, 'Transmission Transgénérationnelle des Traumatismes et Scolarisation des Enfants de Réfugiés du SudEst Asiatique', Perspectives Psychiatriques, 42, 2 (2003), I34-4I; Tiphaine Dequesne and Psychologue Clinicienne, 'Vécu Traumatique, Migratoire et Résilient des Réfugiés Khmers de France après le Génocide Khmer Rouge: Quand la Culture Crie en Silence', in Colloque Terrains d'Asiles: Corps, Espaces, Politiques (Paris, 2008).

59 PTSD entered the American Diagnostic and Statistical Manual of Mental Disorders DSM III classification in I980. On the influence of the DSM worldwide, see Wilbur Scott, 'PTSD in DSMIII: A Case in the Politics of Diagnosis and Disease', Social Problems, 37, 3 (I990), 294-3IO. It was immediately applied to Holocaust survivors: Klaus Kuch and Brian J. Cox, 'Symptoms of PTSD in I24 Survivors of the Holocaust', American Journal of Psychiatry, I49, 3 (I992), 337-40.

${ }^{60}$ J. David, 'Posttraumatic Stress Disorder Among Survivors of Cambodian Concentration Camps', American Journal of Psychiatry, I4I, 5 (I984), 645-50.

${ }^{61}$ James K. Boehnlein, J. David Kinzie, Rath Ben and Jenelle Fleck, 'One-Year Follow-up Study of Posttraumatic Stress Disorder Among Survivors of Cambodian Concentration Camps', The American Journal of Psychiatry, I42, 8 (I985) 956-9.

${ }^{62}$ Richard F. Mollica, Karen Donelan, Svang Tor, James Lavelle, Christopher Elias, Martin Frankel and Robert J. Blendon, 'The Effect of Trauma and Confinement on Functional Health and Mental Health Status of Cambodians Living in Thailand-Cambodia Border Camps', Jama, 270, 5 (I993), 58I-6; Richard F. Mollica, Xingjia Cui, Keith McInnes and Michael Massagli, 'Science-Based Policy for Psychosocial Interventions in Refugee Camps: a Cambodian Example', The Journal of Nervous and Mental Disease, I90, 3 (2002), I58-66; William H. Sack, Richard H. Angell, J. David Kinzie and Ben Rath, 'The Psychiatric Effects of Massive Trauma on Cambodian Children: II. The Family, the Home, and the School', Journal of the American Academy of Child Psychiatry, 25, 3 (I986), 377-83.

63 James K. Boehnlein, J. David Kinzie, Utako Sekiya, Crystal Riley, Kanya Pou and Bethany Rosborough, 'A Ten-year Treatment Outcome Study of Traumatized Cambodian Refugees', The 
Richard Retchman and Didier Fassin have noted, ${ }^{64}$ this data helped shore up the shape and politics of 'new' psychiatric concepts such as PTSD. ${ }^{65}$ Retchman, himself a major voice in the critical response to the arrival of PTSD in European psychiatry, built his clinical experience of this ambiguous reconfiguration of trauma through his work with Cambodian refugees living in France from 1986 onwards. ${ }^{66}$

The Cambodian adolescent project, for instance, provided the opportunity to produce knowledge on both Cambodians and adolescence. ${ }^{67}$ Furthermore, these studies also enabled gendered studies which reinforced and contributed to the debates taking place in Europe and the United States on gender politics. ${ }^{68}$ As a unique site of knowledge the Cambodian camps enabled a reflection on modernity: the adolescents and children of these camps were urban subjects whose experiences would have relevance elsewhere. On the one hand their treatment took place in experimental conditions which even included, due to the lack of resources, control groups in the shape of under-medicalised camps or sections of camps. ${ }^{69}$

Brought back to the West, where many Khao I Dang refugees were eventually resettled, ${ }^{70}$ this knowledge became transferable to a Western urban environment, making explicit the link between international and domestic concerns. ${ }^{71}$ This correspondence between distant crises and the development of 'new' concerns with

Journal of Nervous and Mental Disease, I92, Io (2004), 658-63; Eve B. Carlson and Rhonda RosserHogan, 'Mental Health Status of Cambodian Refugees Ten Years After Leaving Their Homes', American Journal of Orthopsychiatry, 63, 2 (1993), 223-3I.

${ }^{64}$ Didier Fassin and Richard Retchman, L'Empire du Traumatisme, Enquête sur la Condition de Victime (Paris: Flammarion 2007).

${ }^{65}$ Robert G. Blair, 'Risk Factors Associated with PTSD and Major Depression among Cambodian Refugees in Utah', Health and Social Work, 25, I (2000), 23-30; Eve Bernstein Carlson and Rhonda Rosser-Hogan, 'Cross-Cultural Response to Trauma: A Study of Traumatic Experiences and Posttraumatic Symptoms in Cambodian Refugees', Journal of Traumatic Stress, 7, I (I994), 43-58.

${ }^{66}$ Richard Rechtman, 'The Rebirth of PTSD: the Rise of a New Paradigm in Psychiatry', Social Psychiatry and Psychiatric Epidemiology, 39, II (2004), 9I3-5; also, for a distinct interpretation of the invention of PTSD, see Allan Young, 'When Traumatic Memory was a Problem: On the Historical Antecedents of PTSD', in Gerald M. Rosen, Posttraumatic Stress Disorders: Issues and Controversies (Chichester: John Wiley, 2004), I27-46.

67 William H. Sack, Shirley McSharry, Gregory N. Clarke, Ronald Kinney, John Seeley and Peter Lewinsohn, 'The Khmer Adolescent Project: I. Epidemiologic Findings in Two Generations of Cambodian Refugees', The Journal of Nervous and Mental Disease, I82, 7 (1994), 387-95; Stéphanie Nann, 'Les Familles Cambodgiennes en France: Histoires de Vie et Reconstruction', Dialogue, I85, 3 (2009), 55-66; James K. Boehnlein, 'La Place de la Culture dans les Études sur le Traumatisme: une Perspective Américaine', L'Évolution Psychiatrique, 67, 4 (2002), 712-23.

68 Patricia D. Rozée and Gretchen Van Boemel, 'The Psychological Effects of War Trauma and Abuse on Older Cambodian Refugee Women', Women and Therapy, 8, 4 (1990), 23-50.

69 J. David Kinzie, 'Therapeutic Approaches to Traumatized Cambodian Refugees', Journal of Traumatic Stress, 2, I (1989), 75-9I.

70 Aihwa Ong, Buddha is Hiding: Refugees, Citizenship, the New America (Berkeley: University of California Press, 2003).

71 Mary Carol Hopkins, Braving a New World: Cambodian (Khmer) Refugees in an American City (New York: Greenwood Publishing Group, I996); Jeremy Hein, Ethnic Origins: The Adaptation of Cambodian and Hmong Refugees in Four American Cities (New York: Russell Sage Foundation, 2006); Mary Ann Bromley, 'New Beginnings for Cambodian Refugees—or Further Disruptions?' Social Work, 32, 3 (I987), 236-9. 
immigration and globalised societies was matched by humanitarian agencies coming to terms with the realities of exclusion and profound poverty at home. In France as in the United States, many refugees of Cambodian origin failed to thrive compared with their Vietnamese or Chinese contemporaries.

The refugee camps of Cambodia resurrected some of the themes that had been raised in Europe for displaced persons in the I940s and I950s. In many ways these attitudes to refugees highlighted the psychological and psychiatric dangers of apathy and demoralisation which echoed seventy years of refugee rehabilitation practice as studied by Peter Gatrell, for instance. ${ }^{72}$ But there is room for a differentiated approach here, through stressing how these large camps shaped a specific culture of scientific knowledge which enabled university academics to develop projects sustained by humanitarian aid practices. Many medical studies were led by composite teams including local universities and personnel. Although one could develop the impression that this knowledge production was Western focused and even, perhaps, a form of additional violence - even a kind of clinical gaze in a Foucaultian sense this would not reveal the complexity of what went on.

One of the salient features of the medical and social science that took place in the Cambodian camps was, on the contrary, its focus on cultural difference and the role of culture in attitudes to health, which were not unlike the colonial encounters explored by cultural historians of colonial and missionary medicine. ${ }^{73}$ The use of local knowledge and healers in clinical and psychiatric settings were uniquely well documented. ${ }^{74}$ For example, the French psychiatrists Jean-Pierre Hiégel and Colette Hiégel Landrac, both based at Khao I Dang, developed a space which combined traditional healing techniques and Western psychiatry in the midst of a chaotic urban setting. They entitled this combination of medicine and traditional healing 'humanitarian psychiatry', but it could only have developed in the long-term setting of a stable camp environment. ${ }^{75}$ This project was funded over the years by a succession of agencies such as Médecins du Monde or St John's of Malta. As early as I980 MSF doctors noted the need to call in 'Kru Khmer' practitioners to treat unknown psychiatric ailments. ${ }^{76}$ This culturally sensitive approach profoundly impressed those entrusted with the treatment of resettled Cambodians in France. At a time when French and European politics encountered the reality of globalisation and the new diversity of its people, refugees presented new challenges for those who were treating

72 Peter Gatrell, The Making of the Modern Refugee (Oxford; Oxford University Press, 20I3).

73 David Arnold, Imperial Medicine and Indigenous Societies (Manchester: Manchester University Press, I988); David Hardiman and Projit Bihari Mukharji, eds., Medical Marginality in South Asia: Situating Subaltern Therapeutics (London: Routledge, 20I2); Jean-Michel Campagne, 'Santé et Hygiène dans un Camp de Réfugiés: à Propos d'une Expérience avec Médecins sans Frontières dans un Camp de Réfugiés Cambodgiens en Thailande', PhD diss., Bordeaux 2, I994.

${ }^{74}$ Rita Chi-Ying Chung, 'Psychosocial Adjustment of Cambodian Refugee Women: Implications for Mental Health Counseling', Journal of Mental Health Counseling, 23, 2 (200I), II5-26.

75 Jean-Pierre Hiégel and Colette Hiégel Landrac, Vivre et Revivre à Khao I Dang, une Psychiatrie Humanitaire (Paris: Fayard, I996).

${ }^{76}$ Rapport trimestriel, Khao I Dang, I980, Archives MSF (Paris), Thailande, I979-I983, II. 
them. Their belief systems radically challenged the Western foundations of psychiatry or social work. ${ }^{77}$

While this medicine grew in an East-West exchange which showed some of the old colonial fascination for the orient and even orientalism, much science attempted, by contrast, to develop the tools of high technicality and dispassionate epidemiologic surveillance. ${ }^{78}$ The camps as sites of study also provided the possibility of examining newly medicalised groups from conception to the grave. The studies on fertility implied some interventionists and often heavy-handed examination of local cultural practices ${ }^{79}$ or the medical and clinical evaluation of grieving. ${ }^{80} \mathrm{New}$ connections were established between different issues affecting the refugees in the camp environment, such as under-nutrition's impact on mortality, ${ }^{81}$ the rehabilitation of amputees, victims of the extensive minefields ${ }^{82}$ and the deleterious effects of camp life on familial discipline and the rise of criminal delinquency. ${ }^{83}$ From its early days the nature of the medicine and social science practiced in refugee camps was defined as both banal and urgent, as an opportunity to redress and correct and as an epidemiological testing ground. ${ }^{84}$ The camps and refugees presented many of the traditional pathologies of refugees across history. Though some of the more traditional

77 Richard Rechtman, 'L'Apparition des Ancêtres et des Défunts dans les Expériences Traumatiques: Introduction à une Ethnographie Clinique chez les Réfugiés Cambodgiens de Paris', Cahiers d'Anthropologie et Biométrie Humaine, IO, I-2 (I992), I-I9; Gay Becker, Yewoubdar Beyene and Pauline Ken, 'Memory, Trauma, and Embodied Distress: The Management of Disruption in the Stories of Cambodians in Exile', Ethos, 28, 3 (2000), 320-45.

78 Christopher J. Elias, Bruce H. Alexander and Tan Sokly. 'Infectious Disease Control in a Long-term Refugee Camp: the Role of Epidemiologic Surveillance and Investigation', American Journal of Public Health', 80, 7 (I990), 824-8.

79 Kimberley Townsend and Pranee Liamputtong Rice, 'A Baby is Born in Site 2 Camp: Pregnancy, Birth and Confinement Among Cambodian Refugee Women’, in Rice P. Liamputtong and L. Manderson, eds., Maternity and Reproductive Health in Asian Societies (1996), I25-43; Richard F. Mollica, Charles Poole and Svang Tor, 'Symptoms, Functioning, and Health Problems in a Massively Traumatized Population: The Legacy of the Cambodian Tragedy', in Bruce Dorhenwend, ed., Adversity, Stress and Psychopathology (New York: Oxford University Press, I998), 34-5I; Susan E. Holck and Willard Cates, 'Fertility and Population Dynamics in two Kampuchean Refugee Camps', Studies in Family Planning, I3, 4 (I982), II 8-24.

${ }^{80}$ James K. Boehnlein, 'Clinical Relevance of Grief and Mourning among Cambodian Refugees', Social Science and Medicine, 25, 7 (1987), 765-72.

${ }^{81}$ Michael J. Toole, Phillip Nieburg and Ronald J. Waldman, 'The Association Between Inadequate Rations, Undernutrition Prevalence, and Mortality in Refugee Camps: Case Studies of Refugee Populations in Eastern Thailand, I979-I980, and Eastern Sudan, I984-I985', Journal of Tropical Pediatrics, 34, 5 (I988), 218-24.

82 Lindsay French, 'The Political Economy of Injury and Compassion: Amputees on the Thai-Cambodia border', Embodiment and Experience: The Existential Ground of Culture and Self (1994), 69-99.

83 Charles G. Go and Thao N. Le, 'Gender Differences in Cambodian Delinquency: The Role of Ethnic Identity, Parental Discipline, and Peer Delinquency', Crime and Delinquency, 5I, 2 (2005), 22037; Cecile Rousseau and Aline Drapeau, 'Are Refugee Children an At-risk Group? A Longitudinal Study of Cambodian Adolescents', Journal of Refugee Studies, I6, I (2003), 67-8I.

${ }^{84}$ Allen D. Soffer and Henry Wilde, 'Medicine in Cambodian Refugee Camps', Annals of Internal Medicine, I05, 4 (I986), 6I8-2I; Timothy D. Mastro, 'Health Care in Cambodian Refugee Camps', Annals of Internal Medicine, I06, I (I987), I73-4. 
illnesses were the main focus, the camps also enabled (if not authorised) studies of refugee psychosis $^{85}$ or the onset of domestic violence. ${ }^{86}$

Scientific works never entirely de-contextualised the lessons of the Cambodian camps from the historical and political setting in which they were produced, but there was a tension in how they related to this captive sample of a post-genocide society. The 'unique' status of the Cambodians as 'traumatised' people ${ }^{87}$ invited comparative work, including, for instance, an innovative study of torture victims with the victims of dictatorship in Chile. ${ }^{88}$ Cambodians needed education, skills and social opportunities as much as they needed health and food - then the primary focus of emergency relief work. They remained in a situation of continuous emergencies which became the symptoms of a dislocated society in need of reconstruction. The camps bridged the gap between development and humanitarian aid. Their humanitarian needs grew in complexity as a result. As the negotiations between the opposition and the Vietnamese backed regime progressed, humanitarians began to consider their contribution to the rebuilding of Cambodia and to shift their aims from 'emergency relief work' to reconstruction and rehabilitation. ${ }^{89}$ They had worked in an environment which was steeped in new approaches to domestic concerns such as gender violence or PTSD, and they could imagine themselves to be part of the solution because of the profound way in which they had contributed to the definition of Cambodian problems through their observations of refugees in camps.

\section{The Late Rise of Political Humanitarian Voices}

The end of the camps was foreseeable from I989 onwards, following the Vietnamese withdrawal from Cambodia. Though destined to be closed, they remained open for more than three years before the last structure was set on fire by Thai authorities and before elections could take place in May I993 in Cambodia. ${ }^{90}$ These final years were troubled by the very complex positioning of competing forces in the peace process and witnessed the paradoxical remilitarisation of the camps. Humanitarians had long known or suspected that food aid had fuelled the war. This suspicion was occasionally aired but remained largely silenced until the scandal became impossible

85 J. David Kinzie and James J. Boehnlein, 'Post-Traumatic Psychosis among Cambodian Refugees', Journal of Traumatic Stress, 2, 2 (I989), I85-I98.

86 Barbara A. Frye and Carolyn D. D'Avanzo, 'Cultural Themes in Family Stress and Violence Among Cambodian Refugee Women in the Inner City', Advances in Nursing Science, I6, 3 (I994), 64-77.

87 Fassin and Retchman, L'Empire du Traumatisme.

88 Patrick Morris, Derrick Silove, Vijaya Manicavasagar, Robin Bowles, Margaret Cunningham and Ruth Tarn, 'Variations in Therapeutic Interventions for Cambodian and Chilean refugee Survivors of Torture and Trauma: A Pilot Study', Australasian Psychiatry, 27, 3 (I993), 429-35.

89 Nathalie Dupont and Sothik Hok, 'L'Impact de l'Action d'une ONG sur une Politique Nationale. L'Exemple d'un Module de Formation des Enseignants au Cambodge', Revue Internationale d'Éducation de Sèvres, 58 (20II), 37-46.

${ }^{90}$ Refugee policy group, Repatriation, Cambodia a Time for Return, Reconciliation and Reconstruction', unpublished report, Washington and Geneva, Oct. I99I, Archives MSF (Paris), papiers François Jean, ABILE. 
to hide in $1989 .{ }^{91}$ UNBRO had long operated by relying on resources dependent on the Cold War agenda of major state donors such as the United States, Japan, France and Thailand. ${ }^{92}$ In 1989 the thirteen NGOs operating in Site 2 denounced Americanbacked military rearmament of Sihanouk's partisans. ${ }^{93}$ Paradoxically, the Vietnamese withdrawal and the prospect of peace reopened the prospect of the Khmer Rouge's return and genocide. ${ }^{94}$ In 1990 many areas fell under Khmer Rouge military control - including much of the border zone - and their return to power seemed almost inevitable, and these fears were not diminished by the terms of the Paris accord of I991. ${ }^{95}$ Despite the deployment of a very large UN transitional authority in I992, led by the Japanese Yasushi Akashi, and of a large military and policing mission, over I8,000 men strong, under Australian command, humanitarians and observers continued to fear that the Khmer Rouge would resume the genocide interrupted in I979. This genuine anxiety remained the dominant focus of campaigning until at least late I993. $^{96}$

By the beginning of the peace talks in I990, humanitarians in the camps had existed within an epistemic community focused on trauma and genocide stories for over a decade - the I984 film 'the Killing Fields' and its main character, the photojournalist Dith Pran, himself a genocide survivor, had brought the Cambodian Genocide to the forefront of public consciousness. ${ }^{97}$ In August 1990 more than I20 humanitarian workers from the camps signed a petition against the prospect of a peace including the still militarised Khmer Rouge. ${ }^{98}$ Camp experience fuelled bolder political initiatives and the emergence of humanitarian NGOs as lobbying actors in the Cambodian peace process.

At the initiative of Oxfam, an international forum convened in 1988 which met in Brussels and London and which aimed to gather all NGOs working in the camps and Cambodia. Though it never quite managed this feat, it nevertheless represented sixty-seven international NGOs in I990 and eighty-seven by I99I, when it became more formalised. Its range extrended from Socialist Solidarity to Caritas, Christian aid, Lutheran World Service and a range of faith based organisations across Asia,

91 'Feeding Peace or Feeding War?', Diakonia, Bangkok, News from the Jesuit Refugee Services, Nov. I989, I.

92 It was occasionally voiced, however: Asian Watch, a US human rights NGO had produced a report in 1988 entitled 'Khmer Rouge Abuses along the Thai Cambodian Border', Feb. I988, Archives MSF (Paris), papiers François Jean, ABILE.

93 Minutes of the 6th NGO forum, Sept. I989, 'report from the Border', Archives MSF (Paris), papiers François Jean, Droits de l'homme, 7.

${ }^{94}$ Mouvement d'entraide pour le Tiers Monde et la coopération, minutes of the meeting of 29 Nov. I989, Archives MSF (Paris), papiers François Jean, ABILE.

95 Frederick Z. Brown, 'Cambodia in I991: An Uncertain Peace', Asian Survey, 32, I (1992), 88-95.

96 To summarise, the United Nations Advance Mission in Cambodia was subsumed in 1992 within a new larger mission UNTAC (United Nation Transition Authority in Cambodia) I6,ooo soldiers and 3,500 policemen strong. See Grant Curtis, 'Transition to What? Cambodia, UNTAC and the Peace Process', United Nations Research Institute for Social Development, UNRISD, Nov. I993.

97 Kari Rene Hall and Josh Getlin, Beyond the Killing Fields (Reading, Pa: Aperture, I992).

98 'International Aid Workers in Cambodia on the Thai Cambodian Border demand UN Cambodian Seat to be challenged', 6 Aug. I990, Archives MSF (Paris), papiers François Jean, Droits de l'Homme. 
Europe and North America. Oxfam Belgium and United Kingdom convened in the late 1980 os and were joined by Christian Aid in I99I. ${ }^{99}$ MSF was part of the forum but had also conducted other human rights initiatives through its anti-communist offshoot Liberté sans Frontières, which has been studied by Eleanor Davey. ${ }^{100}$ By I990 what became known as a 'sector' was assembled around the new forum which conducted planning and lobbying on behalf of its members. This forum's legitimacy arose from its camp work and it alone could claim to have independent monitoring capacity. In I989 MSF and Médecins du Monde issued a joint call which stressed the importance of their volunteers as 'our teams are on the ground. They have the support of public opinion and international organisations, our volunteers will act as the sentinels of human rights'. ${ }^{101}$

The independence of the forum and its members was grounded in their field experience but its interpretation of neutrality was legitimated by the needs of Cambodians to be protected from predatory politicians. This led the organisation to back unequivocally the Hun Sen government in Phnom Penh. Party to the politics of the peace process, the NGO forum sought legal advice on its potential role in the peace negotiation and decided, on the advice of Tony Jackson of Oxfam, to focus its activities on the Khmer Rouge presence as seat holders at the United Nations and to ask specifically for the 'non involvement of the Khmer Rouge at the UN'. ${ }^{102}$ On 6 November I989 Oxfam and the International Council of Voluntary agencies, who represented eighty-five NGOs, called for the Khmer Rouge to desist from the United Nations. Meanwhile, in I989, the forum hired the British diplomat John Pedler as its diplomatic advisor; he was later replaced by the fiercely anti-Khmer Rouge Belgian consultant Raoul Jennar in I990. ${ }^{103}$ Jennar was contracted to lobby the twelve states of the European Union and the Scandinavian states to convince them to withdraw their support from the coalition including the Khmer Rouge and to pledge more resources for the reconstruction of Cambodia. ${ }^{104}$ Jennar produced vigorously phrased reports and testified on Cambodia to parliaments in Europe and to the US Senate on the dangers of letting the Khmer Rouge grow again. ${ }^{105}$ The forum used its extensive network to lobby all the national states where its organisations worked in order to monitor its progress against the Khmer Rouge. Lobbying was officially the main priority, together with planning for future NGO-centred international development

99 The forum's initial budget was 48,000 dollars in I990, with funding originating from seven large INGOs.

100 Davey, Idealism Beyond Borders.

101 'Au Cambodge Ils Reviennent', Opération Cambodge, I6 Nov. I989, Archives MSF (Paris), papiers François Jean, ABILE; 'Les Khmers Rouges Reviennent: Avons-nous le Droit de ne Rien Faire?', Handicap International, 24 (I990), 2-5.

102 Minutes of the 6th meeting of the NGO Forum, Quaker House, Brussels, 4-6 Sept. I989, Archives MSF (Paris), papiers François Jean, Droits de l'Homme.

${ }^{103}$ Memorandum letter from Lucile de la Brabandere to members of the forum, Oxfam Belgium, 2 Oct. I990. Archives MSF (Paris), papiers François Jean, Droits de l'Homme.

104 Convention entre Lucile de la Brabandere au nom du Forum des ONG et Raould Jennar, 29 Mar. I990, Archives MSF (Paris), papiers François Jean, Droits de l'Homme.

105 Raoul Marc Jennar, Chroniques Cambodgiennes, 1990-1994: Rapports au Forum International des ONG au Cambodge, (Paris: L'Harmattan, I995). 
plans. ${ }^{106}$ Academics were brought in to cast light on the 'new Khmer Rouge'. ${ }^{107}$ In his reports to the forum Raoul Jennar drew bold comparisons between Pol Pot and Hitler, building on the Holocaust reference point of all genocidal regimes, but he also noted that the xenophobic and populist discourse of the 'new Khmer Rouge', manifested in murderous attacks against Vietnamese fishermen, for example in the massacre of March I993, ${ }^{108}$ was not unlike the populist language of far right politicians in Europe such as Jean-Marie Le Pen. ${ }^{109}$

The campaign at the United Nations relied on other allies such as the Quaker United Nations Office. ${ }^{110}$ The campaign failed in the first instance. It did not manage to sideline the Khmer Rouge. The Khmer Rouge only lost their hold over the Cambodian UN seat after the Paris treaty of I99I. They were then replaced as the internationally recognised voice of Cambodia by the transitional Conseil National Suprême, which originally included them too. But the political discredit associated with the genocide proved their undoing. They became the object of sanctions through Resolution 792 in the United Nations on 30 November I992. Ultimately, on I3 April I993, the Khmer Rouge withdrew from the political process and returned to Phnom Malai, which had served as their headquarters during the war against the Vietnamese until I985. For the French speaking press it was a return to the 'maquis', another reference from the Second World War. ${ }^{111}$ Abandoned by the Chinese and without new powerful backers, the movement withered and eventually died with Pol Pot in I998.

The humanitarian lobbying had in effect positioned international NGOs as the objective allies of the long-term winners of the peace transition. The NGO forum expressed the members' collective desire to coordinate humanitarian efforts and provisions in the new Cambodia. NGOs organised in a general meeting which articulated these views in a common declaration calling for sustained UN effort and the exclusion of all Khmer Rouges in February I993. ${ }^{112}$ The opening of Cambodia for humanitarian work turned the country into what international relations specialists have nicknamed an 'NGOland', a polity in which many of the key functions of the state were assisted or supplemented by international aid to the point that this aid restricted real sovereignty. Cambodia became one of the prime examples of this

106 Minutes of the 7th meeting of the NGO Forum, Quaker House, Brussels, 26-27 Feb. I990, Archives MSF (Paris), papiers François Jean, Droits de l'Homme.

107 Christophe Peschoux, Les "Nouveaux" Khmers Rouges: Enquête (1979-199o) Reconstruction du Mouvement et Reconquête des Villages, (Paris: L'Harmattan, I992)

108 Cambodia had received many Vietnamese migrants over the occupation period I978-I989.

109 Raoul Marc Jennar, 'Chroniques Cambodgiennes: Dialogues de Sourds dans un Contexte Volatile', Forum des ONG au Cambodge, Londres, Phnom Pen, Centre Européen de Recherches sur l'Extrême Orient, 7 Sept. I992, Archives MSF (Paris), Papiers François Jean, Boite ABILE, n II.

110 Quaker United Nations Office, 'Policies and Procedures Relevant to the Representation of Cambodia in the United Nations', Archives MSF (Paris), papiers François Jean, Droits de l'Homme.

111 Droit de l'Homme et Solidarité, Agence Cambodge Laos, May 1993, bulletin 29, Archives MSF (Paris), papiers François Jean, ABILE, II.

112 Fax from Action Nord -Sud and Handicap International to MSF, reporting on the meeting of 2 Feb. I993, Archives MSF (Paris), papiers François Jean, Droits de l’Homme. 
post-conflict evolution as it drew in a multitude of developmental and relief agencies financed by a institutional donors. Many NGO workers trained in the camps, both Cambodian nationals and international workers, migrated into the new troubled 'democracy' in I992-3, where they met around sixty other NGOs invited in the country a few years earlier by the pro-Vietnamese government. ${ }^{113}$ Meanwhile, the Cambodian diaspora, object of much concern in relation to their traumatic past, which had settled permanently in the various countries where UNHCR policies had landed them, was called upon as part of the new international effort for Cambodia. A new era of triumphantly coordinated humanitarian work seemed to be heralded, and soon Cambodia featured the highest concentration of NGO workers in the world. The forum and its development plans represented the coming of age of a system which set its objectives much higher than mere emergency response. By February I99I the NGO Forum was a sufficiently important for the Hun Sen government minister of planning to address it and ask for its support. ${ }^{114}$ An epistemic community born in the camps imagined itself an international system.

\section{Conclusion}

The role of the camps as the cradle of this community is significant. But, at a time of doubts and challenges, embodied in the soul searching World Humanitarian Summit of 20I6, the camps retain an aura that is unique. Humanitarian commemorative focal points (lieux de mémoire) are few. If some of the contemporary refugee camps have become, with the passage of time, sites of 'dark tourism', ${ }^{115}$ it seems unlikely that major commemorative spaces will emerge in the dusty fields of Site 2. Yet in a relief sector which notoriously suffers from chronic amnesia, the desire to remember and chronicle, through self-published diaries and the dissemination of photographic evidence, is even more noticeable. Furthermore, many of those who recall their formative years in these autobiographic documents are still practitioners ${ }^{116}$ - still engaged as internationalists. Some have continued a career at home in refugee health centres or organisations, others have had important careers in the United Nations

113 'Standard Operating Procedures for Medical Activities during the Repatriation Process', I8 Mar. I992, Archives MSF (Paris), Thailande, Khao I Dang I990-I992 rapports Kit Medi RPI.

1144 Feb. I99I, Archives MSF (Paris), papiers François Jean, Droits de l'Homme.

115 Ashley Carruters and Boy Tranh Huynh-Beattie, 'Dark Tourism, Diasporic Memory and Disappeared History', in Yuk Wah Chan, ed., The Chinese/Vietnamese Diaspora: Revisiting the Boat People (London: Routledge, 20II), I47-60; Rachel Hughes, 'Nationalism and Memory at the Tuol Sleng Museum of Genocide Crimes, Cambodia', in C. Hodgkin and S. Radstone, eds., Contested Pasts: the Politics of Memory (London: Routledge, 2003),I75-92; Rachel Hughes, 'The Abject Artefacts of Memory: Photographs from Cambodia's Genocide', Media, Culture and Society, 25 (2003), 23-44; Scott Laderman, Tours of Vietnam: War, Travel Guides and Memory (Durham: Duke University Press, 2009); Judy Ledgerwood, 'The Cambodian Tuol Sleng Museum of Genocidal Crimes: National Narrative', Museum Anthropology, 2I, I (I997), 82-98; Jean-Louis Margolin, 'L'Histoire Brouillée. Musées et Mémoriaux du Génocide Cambodgien', Gradhiva. Revue d'Anthropologie et d'Histoire des Arts, 5 (2007), 84-95.

116 Young 'My Heart It Is Delicious'. 
system or large NGOs. ${ }^{117}$ The community of practice in which they had taken part has had a profound influence worldwide.

Despite its early promises, the rebuilding of Cambodia has not proven as positive an experience as the camps themselves, despite their political ambiguity. The recollection of the Cambodian camps as an idealised space for collaborations, 'joined-up thinking', common norms and training smooth over the barely acknowledged tensions or the anxieties arising from blatant manipulation of $\operatorname{aid}^{118}$ for the purpose of continued warfare $^{119}$ or the shoring up of competing political forces. ${ }^{120}$ What remains of this episode today is the memory of a way of thinking about collaboration and cooperation, less a concept than nostalgia for genuinely constructive exchanges in a worldwide humanitarian market. ${ }^{121}$

Cambodian camps may have become the cradle of sentimental idealism rather than the matrix of a hegemonic new humanitarian system, but their 'prolonged emergency' existence enabled volunteers to develop self-narratives of professionalism and experience. ${ }^{122}$ The idea of permanent emergency, since then theorised by Mark Duffield and Didier Fassin, came into existence through the experience of these interminable containments of population displacements. ${ }^{123}$ In a crucial way the Cambodian camps comforted the spatial and cultural separation between aid workers and recipients of aid: Volag workers could not reside in camps, and nothing could bridge entirely the unspeakable epistemic distance of the victims from their helpers. Although research on trauma, sexual and domestic violence as well as on crime dispelled any illusions on what a refugee community might be, it also invited new explanations. The disrupted and displaced universe of refugee camps challenged expatriates to make sense of not just refugees but also themselves in the face of genocide. Humanitarians could attempt to reorder and make sense of their encounters discursively only through recourse to trauma and references to genocide. This became most obvious in the form their late awakening to the politics surrounding them. Genocide trumped all ambiguities and past compromises.

117 Norah Niland, for example, became a leading figure in the field of protection. She ended her UN career as director of human rights in UNAMA and Representative of the UN High Commissioner for HR.

118 Rony Brauman, 'Les Liaisons Dangereuses du Témoignage Humanitaire et des Propagandes Politiques', Recherches (2007), I88-204; Gilbert Wasserman, 'De l'Instrumentalisation de l'Humanitaire à celle de la Mémoire', Mouvements, 33, 3 (2004), I25-3I .

119 Barber, 'Feeding Refugees, or War?', 8-I4.

120 French, 'From Politics to Economics', 427-70.

121 Alain Destexhe, L'Humanitaire Impossible: Deux Siècles d'Ambiguïté (Paris: Armand Colin, I993).

122 Richard Heinzl, Cambodia Calling (Misssissauga: John Wiley, 2008).

123 Fassin Didier and Mariella Pandolfi, eds., Contemporary States of Emergency: the Politics of Military and Humanitarian Interventions (New York: Zone Books, 20I0); Mark Duffield, 'NGOs, Disaster Relief and Asset Transfer in the Horn: Political Survival in a Permanent Emergency', Development and Change, 24, I (1993), I3I-58; ibid. 'NGO Relief in War Zones: Towards an Analysis of the New Aid Paradigm', Third World Quarterly, I8, 3 (I997), 527-42. 